\title{
EVALUASI DAN INVENTARISASI ASET BEKAS TANAH KAS DESA MENGGUNAKAN SIG (Studi Kasus : Kecamatan Lakarsantri, Kota Surabaya)
}

\author{
Rizky Sandy, Yanto Budisusanto, Udiana Wahyu D \\ Jurusan Teknik Geomatika, Fakultas Teknik Sipil dan Perencanaan, Institut Teknologi Sepuluh Nopember (ITS) \\ Jl. Arief Rahman Hakim, Surabaya 60111 \\ e-mail: yanto_b@geodesy.its.ac.id, udiana@geodesy.its.ac.id
}

\begin{abstract}
Abstrak
Tanah kas desa adalah tanah yang dikuasai desa sebagai kekayaan desa. Namun karena status desa berubah menjadi kelurahan, seluruh tanah kas desa beralih menjadi aset milik kelurahan (UURI No.5, 1979). Kota Surabaya merupakan salah satu kota yang terkena imbas dari peraturan tersebut. Pada awalnya kota Surabaya dibagi menjadi 38 lingkungan dan 103 desa. Dalam peleburan menjadi kelurahan, 38 lingkungan diubah menjadi 60 kelurahan dan 103 desa menjadi 103 kelurahan, sehingga total di Kota Surabaya ada 163 kelurahan (Tobing, 2009). Selain itu pemanfaatan tanah kas desa juga harus sesuai dengan rencana tata ruang wilayah dalam kabupaten/kota (PP No.16, 2004). Oleh karena itu diperlukam adanya suatu kegiatan untuk inventarisasi dan evaluasi terhadap bekas tanah kas desa. Penelitian ini bertempat di Kecamatan Lakarsantri kota Surabaya dan bertujuan untuk melakukan pemetaan terhadap bekas tanah kas desa, membangun Sistem Informasi Geografis (SIG) dan mengevaluasi penggunaan lahan dari tanah kas desa tersebut terhadap rencana tata ruang wilayah kota Surabaya tahun 2013. Kegiatan ini menggunakan data spasial berupa peta digital kota Surabaya skala 1:5000 dan peta rencana tata ruang wilayah kota Surabaya sedangkan data non-spasial berupa data tabular asset bekas tanah kas desa yang didapatkan dari Dinas Pengelolaan Bangunan dan Tanah Pemerintah Kota Surabaya. Dengan menggunakan SIG pelaksanaan analisa ditemukan bekas tanah kas desa paling banyak berupa bangunan dan dari hasil evaluasi penggunaan lahan bekas tanah kas desa sebagian besar masih belum sesuai dengan rencana tata ruang wilayah kota Surabaya terutama untuk penggunaan lahan kawasan dagang dan jasa.
\end{abstract}

Kata kunci : Bekas Tanah Kas Desa, Sistem Informasi Geografis, Rencana Tata Ruang Wilayah

\section{PENDAHULUAN}

Peranan tanah bagi pemenuhan berbagai kebutuhan manusia semakin lama semakin meningkat sementara tanah yang ada semakin sempit karena penggunaannya untuk berbagai macam kebutuhan diantaranya untuk tempat bermukim, tempat usaha dan untuk tanah pertanian. Negara sebagai organisasi kekuasaan tertinggi dari seluruh rakyat Indonesia diberi wewenang untuk mengatur dan menyelenggarakan kekayaan alam untuk kemakmuran rakyat (UURI Pasal 16, 1945). Negara kemudian memberi kewenangan untuk mengatur dan dalam pelaksanaannya dikuasakan pada daerah dengan tetap berpegang pada tujuan utama yaitu sebesar-besar untuk kemakmuran rakyat.

Pemerintah daerah kemudian melakukan usaha untuk melakukan pemanfaatan ruang dengan mengeluarkan Rencana Tata Ruang Wilayah (RTRW). Pemanfaatan ruang tidak terlepas dari penggunaan tanah, sebab tanah merupakan obyek utama dalam upaya memanfaatkan ruang (PP No.16, 2004). Salah satu yang menjadi obyek untuk pemanfaatan ruang adalah tanah kas desa. Kecamatan Lakarsantri merupakan salah satu kecamatan yang memiliki cukup banyak aset Bekas Tanah Kas Desa, baik yang sudah dimanfaatkan maupun yang masih belum. Kecamatan Lakarsantri terdiri dari 6 kelurahan yakni kelurahan Bangingan, Jeruk, Lakarsantri, Lidah kulon, Lidah wetan dan Sumur welut.

Saat ini bekas tanah kas desa di kecamatan Lakarsantri masih belum sesuai dengan kondisi yang ada di lapangan. Diperlukan suatu kegiatan inventarisasi untuk melakukan pendataan sekaligus mengetahui penggunaan dan pemanfaatan tanah kas desa di kecamatan Lakarsantri. Demi tercapainya hal tersebut diperlukan adanya suatu sistem yang dapat menyediakan informasi yang lengkap mengenai BTKD baik dari segi spasial maupun non-spasial. Salah satu langkah yang dapat digunakan adalah 
dengan pembuatan Sistem Informasi Geografis (SIG). Dengan terbentuknya suatu sistem informasi geografis ini diharapkan dapat membantu pengambilan keputusan bagi pemerintah kota Surabaya terkait dengan pemanfaatan dan penataan ruang yang berhubungan dengan bekas tanah kas desa.

\section{METODOLOGI PENELITIAN}

\section{A. Lokasi Penelitian}

Lokasi yang digunakan adalah di kota Surabaya terletak antara $07^{\circ} 9^{\prime \prime}$ - $07^{\circ} 21^{\prime \prime}$ Lintang Selatan dan $112^{\circ} 36^{\prime \prime}-112^{\circ} 54^{\prime \prime}$ Bujur Timur. Sebagian besar wilayahnya merupakan dataran rendah dengan ketinggian 3-6 meter diatas permukaan air laut, kecuali di wilayah Selatan ketinggian 25 50 meter di atas permukaan air laut.

\section{B. Rancangan Penelitian}

Perancangan penelitian ini terbagi dalam tiga hal utama yang merupakan proses untuk melaksanakan dan menghasilkan sistem informasi geografis. Tahap-tahap tersebut terdiri dari pengumpulan data, pengolahan data serta hasil dan analisa. Untuk lebih jelasnya dapat dilihat pada gambar 1.

\section{Data Yang Digunakan}

Penelitian ini menggunakan data spasial berupa peta garis kota Surabaya tahun 2002 skala 1:5000, citra WorldView-2 tahun 2012 dan peta rencana tata ruang wilayah tentang penggunaan lahan tahun 2013. Sedangkan data non spasial yang digunakan adalah data tabular aset bekas tanah kas desa dari Dinas Pengelolaan Bangunan dan Tanah kota Surabaya serta foto dan dokumentasi dari aset BTKD kecamatan Lakarsantri.

\section{HASIL DAN PEMBAHASAN}

Pada bagian ini akan ditampilkan hasil dari pelaksanaan penelitian yang telah dilakukan mengenai bekas tanah kas desa di kecamatan Lakarsantri kota Surabaya.

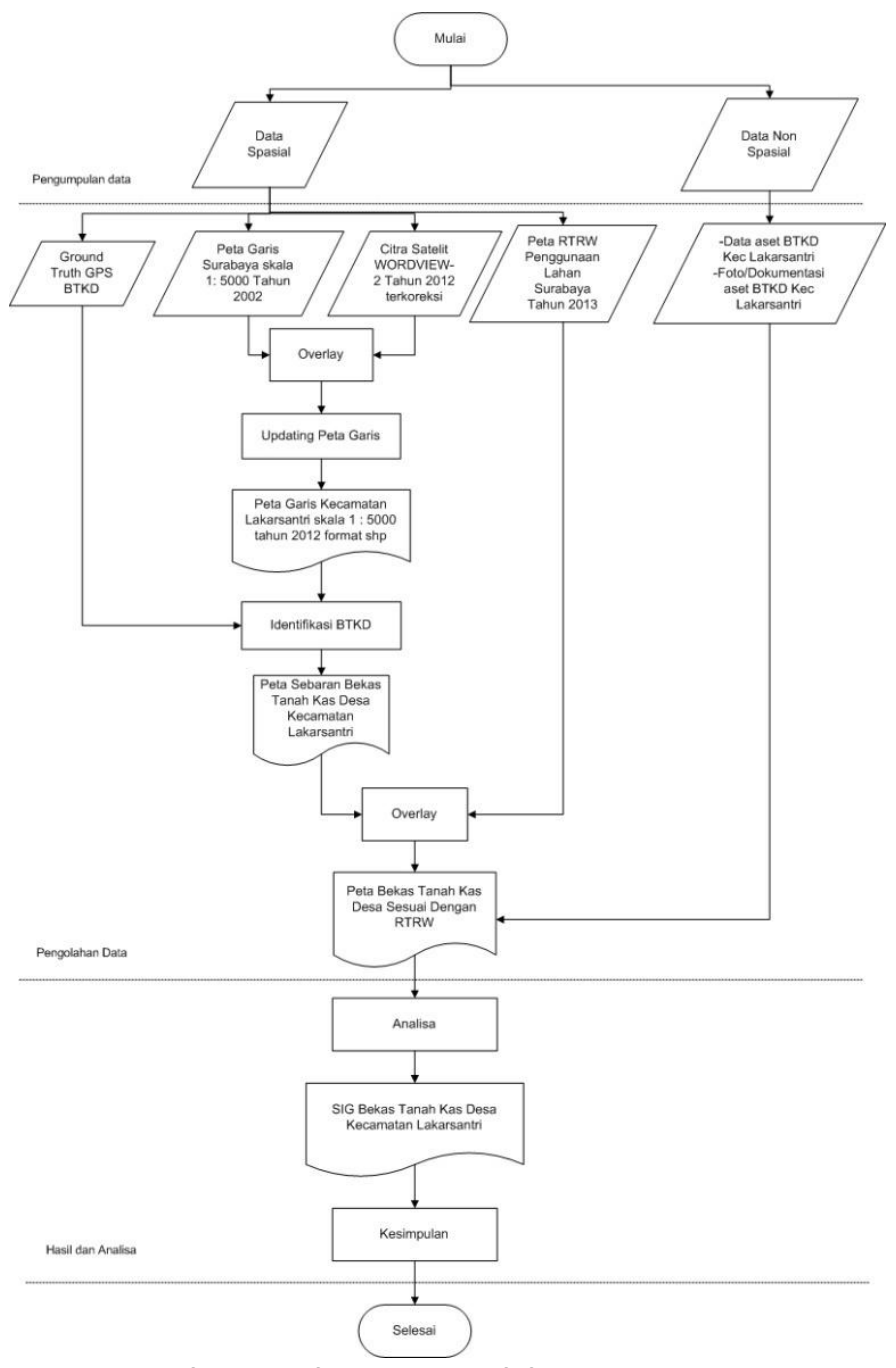

Gambar 1. Tahapan Pengolahan Data

\section{A. Analisa Bekas Tanah Kas Desa}

Berdasarkan dari hasil pengumpulan data dari Dinas Pengelolaan Bangunan dan Tanah Kota Surabaya yang mencakup lokasi Bekas Tanah Kas Desa dan juga dari beberapa Kelurahan di Surabaya dan juga data lapangan didapatkan hasil berupa Peta Sebaran Bekas Tanah Kas Desa tahun 2013 di Kecamatan Lakarsantri. Berdasar hasil analisa yang telah diperoleh dari perangkat lunak sistem informasi geografis, jumlah bekas tanah kas desa yang ada di kecamatan Lakarsantri sebanyak 51 buah sedangkan total luas bekas tanah kas desa di kecamatan Lakarsantri tercatat sebesar $519.212 \mathrm{~m}^{2}$.

\section{B. Analisa Hasil Sebaran BTKD}

Gambar 2 merupakan hasil peta sebaran BTKD di kecamatan Lakarsantri. 


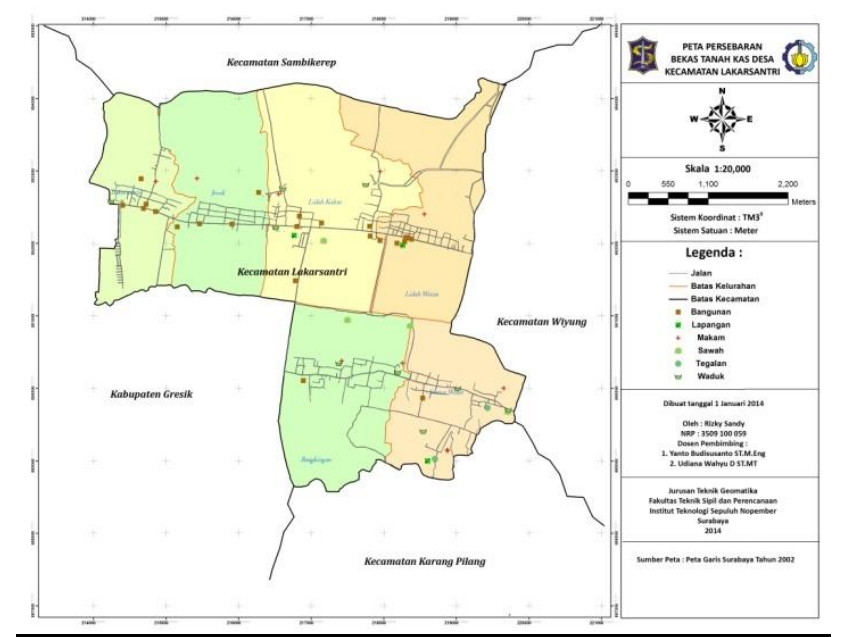

Gambar 2. Peta Sebaran Bekas Tanah Kas Desa Kecamatan Lakarsantri

Bekas tanah kas desa yang telah di inventarisasi terbagi dalam 6 kelurahan. Dari kelurahankelurahan tersebut didapat hasil analisa seperti berikut ini

- Kelurahan Lakarsantri

Kelurahan Lakarsantri memiliki 7 BTKD. Dari semua BTKD tersebut hanya ada 1 BTKD yang masih berupa waduk, sedangkan 6 BTKD yang lain sudah dimanfaatkan sebagai kantor pemerintahan, fasilitas agama dan fasilitas sosial. Untuk keterangan lebih jelasnya bisa dilihat pada tabel 1.

Tabel 1. Tabel Bekas Tanah Kas Desa Kelurahan Lakarsantri.

\begin{tabular}{|c|c|c|c|c|}
\hline Nomor & No GS & Alamat & Pemanfaatan & $\operatorname{Luas}\left(m^{2}\right)$ \\
\hline 1 & 289/S/91 & $\begin{array}{c}\text { Lakarsantri } \\
\text { RT.03 } \\
\text { RW.01 }\end{array}$ & Mushola Al-Kautsar & 694 \\
\hline 2 & $300 / \mathrm{S} / 91$ & - & SDN III & 1812 \\
\hline 3 & $302 / \mathrm{S} / 91$ & $\begin{array}{c}\text { Lakarsantri } \\
\text { RT.01 } \\
\text { RW.03 }\end{array}$ & Waduk & 6618 \\
\hline 4 & $303 / S / 91$ & $\begin{array}{c}\text { Lakarsantri } \\
\text { RT.03 } \\
\text { RW.01 }\end{array}$ & Pasar KMS,SDN 1 & 5186 \\
\hline 5 & $304 / S / 91$ & $\begin{array}{c}\text { Lakarsantri } \\
\text { RT.03 } \\
\text { RW.01 }\end{array}$ & $\begin{array}{c}\text { Punden, TK, Warung } \\
\text { PKL }\end{array}$ & 1208 \\
\hline 6 & $305 / S / 91$ & - & Makam Utara RW 01 & 7210 \\
\hline 7 & $306 / S / 91$ & $\begin{array}{c}\text { Lakarsantri } \\
\text { RT.03 RW. } \\
01\end{array}$ & $\begin{array}{c}\text { Kantor } \\
\text { Kelurahan,SDN } \\
\text { 2,Lapangan,Sawah }\end{array}$ & 93299 \\
\hline
\end{tabular}

- Kelurahan Jeruk

Kelurahan Jeruk mempunyai 5 BTKD. Semua BTKD di kelurahan ini sudah dimanfaatkan baik menjadi kantor kelurahan, puskesmas, makam dan lain-lain. Untuk keterangan lebih jelasnya dapat dilihat pada tabel 2 .

\section{Tabel 2. Tabel Bekas Tanah Kas Desa Kelurahan} Jeruk.

\begin{tabular}{|c|c|c|c|c|}
\hline Nomor & No GS & Alamat & Pemanfaatan & $\operatorname{Luas}\left(m^{2}\right)$ \\
\hline 1 & $122 / S / 91$ & $\begin{array}{l}\text { Jl Jeruk Gg. } \\
\text { Makam RT04 } \\
\text { RW01 } \\
\text { Kelurahan } \\
\text { Jeruk }\end{array}$ & $\begin{array}{l}\text { Makam dan } \\
\text { Pos Hansip }\end{array}$ & 8793 \\
\hline 2 & $124 / S / 91$ & $\begin{array}{c}\text { Jl Raya Jeruk } \\
\text { RT01 RW03 }\end{array}$ & SDN Jeruk 2 & 1620 \\
\hline 3 & $125 / S / 91$ & $\begin{array}{c}\text { Jl Raya Jeruk - } \\
\text { Selatan } \\
\text { Puskesmas }\end{array}$ & $\begin{array}{l}\text { Waduk dan } \\
\text { Puskesmas }\end{array}$ & 11696 \\
\hline 4 & $126 / S / 91$ & $\begin{array}{l}\text { Jl Raya Jeruk } \\
\text { RT01 RW02 }\end{array}$ & $\begin{array}{c}\text { Kantor Lurah, } \\
\text { SDN Jeruk I } \\
\text { dan III, } \\
\text { Lapangan } \\
\text { Olah Raga, TK } \\
\text { PKK }\end{array}$ & 20266 \\
\hline 5 & $129 / \mathrm{S} / 91$ & $\begin{array}{l}\text { Banjar Mlati } \\
\text { Gg. Makam } \\
\text { RT06 RW03 }\end{array}$ & $\begin{array}{c}\text { Makam Islam } \\
\text { RW3 }\end{array}$ & 5098 \\
\hline
\end{tabular}

- Kelurahan Lidah Kulon

Di kelurahan Lidah Kulon terdapat 14 BTKD. Diantaranya ada 4 BTKD yang belum dimanfaatkan yakni 2 waduk, 1 telaga dan 1 sawah. Sedangkan 10 BTKD lainnya sudah berupa bangunan pemerintahan, kesehatan dan tempat ibadah. Untuk keterangan lebih jelasnya bisa dilihat pada tabel 3.

Tabel 3. Tabel Bekas Tanah Kas Desa Kelurahan Lidah Kulon.

\begin{tabular}{|c|c|c|c|c|}
\hline Nomor & No GS & Alamat & Pemanfaatan & $\operatorname{Luas}\left(m^{2}\right)$ \\
\hline 1 & 103/S/91 & $\begin{array}{l}\text { Lidah Kulon - } \\
\text { Pedukuhan Sepat }\end{array}$ & $\begin{array}{c}\text { SDN I dan SDN } \\
\text { II }\end{array}$ & 7884 \\
\hline 2 & 104/S/91 & $\begin{array}{l}\text { Pedukuhan Lidah } \\
\text { Kulon }\end{array}$ & $\begin{array}{c}\text { Lidah Kulon } \\
\text { dan Puskesmas }\end{array}$ & 12838 \\
\hline 3 & $105 / S / 91$ & $\begin{array}{c}\text { Lidah Kulon - } \\
\text { Pedukuhan Sepat }\end{array}$ & $\begin{array}{l}\text { Makam RW III } \\
\text { dan RW V }\end{array}$ & 7418 \\
\hline 4 & 106/S/91 & $\begin{array}{l}\text { Lidah Kulon - } \\
\text { Pedukuhan Lidah } \\
\text { Kulon }\end{array}$ & $\begin{array}{l}\text { Makam RW I } \\
\text { dan RW II }\end{array}$ & 6056 \\
\hline
\end{tabular}




\begin{tabular}{|c|c|c|c|c|}
\hline 5 & $107 / S / 91$ & $\begin{array}{l}\text { Lidah Kulon - } \\
\text { Pedukuhan Lidah } \\
\text { Kulon }\end{array}$ & $\begin{array}{c}\text { Gedung Serba } \\
\text { Guna / } \\
\text { Rencana Pasar }\end{array}$ & 1929 \\
\hline 6 & 108/S/91 & $\begin{array}{l}\text { Lidah Kulon - } \\
\text { Pedukuhan Lidah } \\
\text { Kulon }\end{array}$ & $\begin{array}{l}\text { Waduk RW I } \\
\text { dan II }\end{array}$ & 9306 \\
\hline 7 & 109/S/91 & Sepat Lidah Kulon & $\begin{array}{l}\text { Waduk RW III } \\
\text { dan V }\end{array}$ & 17088 \\
\hline 8 & 110/S/91 & $\begin{array}{l}\text { Lidah Kulon RW IV } \\
\text { (Wisma Lidah } \\
\text { Kulon) }\end{array}$ & Kantor PKK & 1230 \\
\hline 9 & 111/S/91 & Sepat Lidah Kulon & Tlogo Sepat & 6890 \\
\hline 10 & 112/S/91 & $\begin{array}{l}\text { Jalan Raya Lidah } \\
\text { Kulon RW III }\end{array}$ & TK PKK & 382 \\
\hline 11 & $113 / S / 91$ & $\begin{array}{l}\text { Jalan Mangono } \\
\text { Lidah }\end{array}$ & Balai RWIII & 905 \\
\hline 12 & 114/S/91 & $\begin{array}{l}\text { Jalan Menganti } \\
\text { Lidah Wetan }\end{array}$ & Sawah & 15458 \\
\hline 13 & 117/S/91 & Jalan Lidah Wetan I & SMAN 13 & 900 \\
\hline
\end{tabular}

- Kelurahan Lidah Wetan

Di kelurahan Lidah Wetan terdapat 7 BTKD. Semua BTKD tersebut sudah dimanfaatkan menjadi bangunan untuk kepentingan pemerintahan maupun pendidikan. Salah satu BTKD didapat dari hasil ruislag atau tukar guling dengan PT. Bina Maju Mitra Sejati. Untuk keterangan lebih jelasnya bisa dilihat pada tabel 4.

Tabel 4. Tabel Bekas Tanah Kas Desa Kelurahan Lidah Wetan.

\begin{tabular}{ccccc}
\hline Nomor & NoGS & Alamat & Pemanfaatan & Luas $\left(\mathbf{m}^{2}\right)$ \\
\hline 1 & $101 / \mathrm{S} / 91$ & Lidah Wetan & Makam & 7884 \\
2 & Lidah Wetan & SMP, SMK, TK & 12838 \\
3 & Lidah Wetan & $\begin{array}{c}\text { Kantor } \\
\text { Kelurahan } \\
\text { Lidah Wetan } \\
4\end{array}$ & 7418 \\
& Lidah Wetan & $\begin{array}{c}\text { Sekolah MI } \\
\text { Sekolahan }\end{array}$ & 6056 \\
5 & LDN, SMP 28, & \\
& & $\begin{array}{c}\text { Kantor UPTD } \\
\text { (Hasil tukar } \\
\text { guling dengan } \\
\text { Bukit Mas) }\end{array}$ & 1929 \\
6 & Lidah Wetan & $\begin{array}{c}\text { Lapangan } \\
\text { Sepak Bola }\end{array}$ & 9306 \\
7 & Lidah Wetan & Sentra PKL & 17088 \\
\hline
\end{tabular}

- Kelurahan Sumur Welut

Di kelurahan Sumur Welut terdapat 11 BTKD. Sebagian lahan BTKD di kelurahan ini digunakan untuk pengairan dan penghijauan. Sebagian yang lain digunakan untuk makam warga di kelurahan tersebut. Untuk keterangan lebih jelasnya bias dilihat pada tabel 5 .

Tabel 5. Tabel Bekas Tanah Kas Desa Kelurahan Sumur Welut.

\begin{tabular}{|c|c|c|c|c|}
\hline Nomor & NoGS & Alamat & Pemanfaatan & $\operatorname{Luas}\left(m^{2}\right)$ \\
\hline 1 & $307 / S / 91$ & $\begin{array}{c}\text { RT 02/ RW } \\
\text { II }\end{array}$ & Makam Islam & 3634 \\
\hline 2 & $308 / S / 91$ & $\begin{array}{c}\text { Bendungan } \\
01 / \mathrm{III}\end{array}$ & $\begin{array}{c}\text { Makam Islam } \\
\text { Bendungan } \\
\text { Barat }\end{array}$ & 718 \\
\hline 3 & 309/S/91 & $\begin{array}{c}\text { Bendungan } \\
03 \text { / III }\end{array}$ & $\begin{array}{l}\text { Pengairan } \\
\text { Sawah } \\
\text { (Waduk) }\end{array}$ & 3011 \\
\hline 4 & $311 / S / 91$ & $\begin{array}{c}\text { RT } 01 \text { / RW } \\
\text { II }\end{array}$ & Sawah & 12934 \\
\hline 5 & $312 / S / 91$ & $\begin{array}{c}\text { RT } 01 \text { /RW } \\
\text { II }\end{array}$ & $\begin{array}{l}\text { Waduk } \\
\text { (Pesapen } \\
\text { Timur) }\end{array}$ & 1636 \\
\hline 6 & $313 / S / 91$ & $\begin{array}{c}\text { RT } 03 \text { /RW } \\
\text { II }\end{array}$ & Tegalan & 1797 \\
\hline 7 & $318 / S / 91$ & $\begin{array}{c}\text { Bendungan } \\
03 / \mathrm{III}\end{array}$ & $\begin{array}{c}\text { Tegalan, } \\
\text { Waduk dan } \\
\text { Penghijauan }\end{array}$ & 4649 \\
\hline 8 & $319 / S / 91$ & $\begin{array}{c}\text { Sumur } \\
\text { Welut } 04 / 1\end{array}$ & Balai RW I, TK & 1498 \\
\hline 9 & $321 / S / 91$ & $\begin{array}{c}\text { Bendungan } \\
01 \text { / III }\end{array}$ & $\begin{array}{c}\text { Makam Islam } \\
\text { Bendungan } \\
\text { Timur }\end{array}$ & 1245 \\
\hline 10 & $330 / \mathrm{S} / 91$ & $\begin{array}{c}\text { Bendungan } \\
03 / \mathrm{III}\end{array}$ & $\begin{array}{c}\text { Lapangan } \\
\text { Sepak Bola } \\
\text { Gunung Bang }\end{array}$ & 6516 \\
\hline 11 & $331 / S / 91$ & $\begin{array}{c}\text { RT } 05 \text { /RW } \\
\text { ॥ }\end{array}$ & $\begin{array}{c}\text { Penampunga } \\
\text { n Air Hujan / } \\
\text { Waduk } \\
\text { Pesapen Barat }\end{array}$ & 25196 \\
\hline
\end{tabular}

- Kelurahan Bangkingan

Kelurahan Bangkingan memiliki 7 BTKD. Sama seperti kelurahan yang lain, di kelurahan ini lahan BTKD digunakan untuk kantor pemerintahan, sawah dan makam. Untuk lebih jelasnya bisa dilihat pada tabel 6 .

Tabel 6. Tabel Bekas Tanah Kas Desa Kelurahan Bangkingan

\begin{tabular}{c|cccc}
\hline Nomor & NoGS & Alamat & Pemanfaatan & Luas $\left(m^{2}\right)$ \\
\hline 1 & $151 / S / 9$ & RW I & Sawah & 57533 \\
\hline
\end{tabular}




\begin{tabular}{|c|c|c|c|c|}
\hline & 1 & & & \\
\hline 2 & $\begin{array}{c}152 / \mathrm{S} / 9 \\
1\end{array}$ & $\begin{array}{c}\text { Dukuh } \\
\text { Karang } \\
\text { Ploso RW II }\end{array}$ & Sawah & 43431 \\
\hline 3 & $\begin{array}{c}153 / S / 9 \\
1\end{array}$ & RW I & $\begin{array}{c}\text { Punden dan } \\
\text { Makam }\end{array}$ & 2472 \\
\hline 4 & $\begin{array}{c}154 / S / 9 \\
1\end{array}$ & RW I & Waduk & 3135 \\
\hline 5 & $\begin{array}{c}155 / S / 9 \\
1\end{array}$ & RW II & $\begin{array}{l}\text { Makam dan } \\
\text { Punden }\end{array}$ & 5187 \\
\hline 6 & $\begin{array}{c}156 / S / 9 \\
1\end{array}$ & RW II & Waduk & 7425 \\
\hline 7 & $\begin{array}{c}157 / S / 9 \\
1\end{array}$ & RW III & $\begin{array}{c}\text { Kantor } \\
\text { Kelurahan }\end{array}$ & 25727 \\
\hline
\end{tabular}

Berdasarkan dari tabel-tabel diatas dapat dianalisa jumlah penggunaan lahan bekas tanah kas desa sesuai dengan jenis pemanfaatannya dan didapat hasil seperti pada gambar 3.

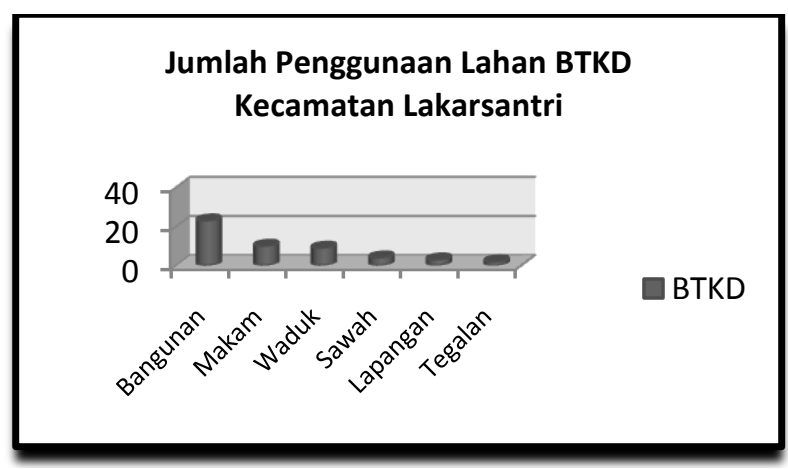

Gambar 3. Grafik Jumlah Penggunaan Lahan BTKD

Pada gambar 3 tertera bahwa BTKD yang paling banyak digunakan untuk bangunan dengan jumlah 23 bidang kemudian makam dengan 10 bidang lalu waduk 9 bidang, sawah 4 bidang, lapangan 3 bidang dan tegalan dengan 2 bidang.

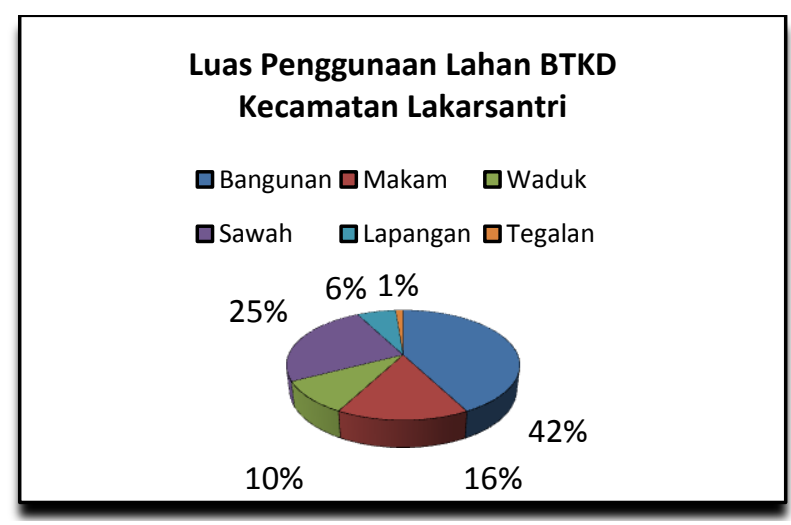

Gambar 4. Grafik Luas Bekas Tanah Kas Desa Kecamatan Lakarsantri
Salah satu faktor yang menjadi penentu jenis pemanfaatan dari tanah kas desa adalah faktor geografis atau lokasi. Hal ini dapat diketahui dengan melihat pada penelitian terdahulu oleh Haryanto (2006). Pada penelitian tersebut area yang menjadi studi adalah kelurahan Keputih. Hasil inventarisasi menunjukkan sekitar $88 \%$ dari total BTKD yang ada berupa tambak. Hal ini dapat dimaklumi karena secara geografis sebelah timur dari kecamatan sukolilo merupakan daerah pesisir. Sehingga berdasar pola pemanfaatannya, aset yang berpotensi adalah tambak. Hasil inventarisasinya dapat dilihat pada gambar 5 berikut:

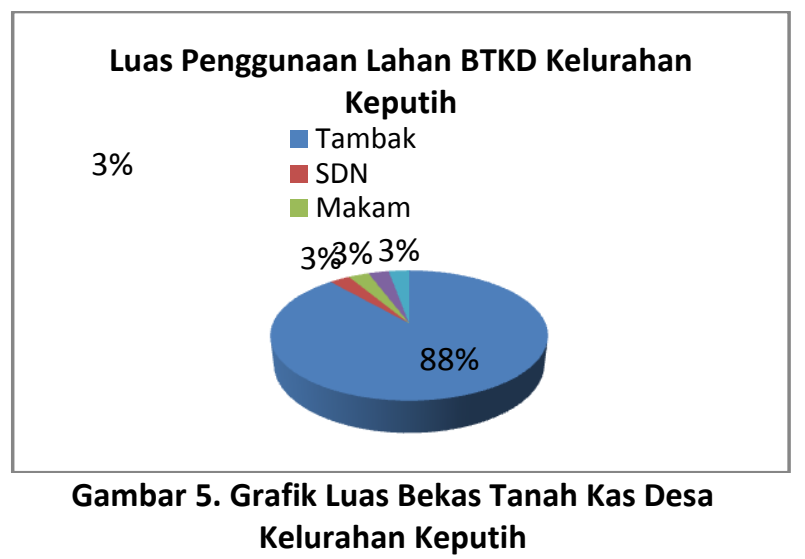

C. Evaluasi Penggunaan Lahan Bekas Tanah Kas Desa Sesuai dengan Rencana Tata Ruang Wilayah kota Surabaya tahun 2013

Dalam kondisi sebenarnya, penggunaan lahan BTKD di kecamatan Lakarsantri masih belum sesuai dengan rencana tata ruang wilayah kota Surabaya tentang penggunaan lahan. Sesuai dengan diterbitkannya Peraturan Pemerintah Nomor 16 (Tobing, 2009). Maka dari itu, penulis melakukan evaluasi terhadap ketidaksesuaian penggunaan lahan BTKD. Metode yang digunakan yakni dengan melakukan overlay layer BTKD dengan layer kawasan yang sesuai dengan peta RTRW.

Setelah dianalisa, penggunaan lahan BTKD di kecamatan Lakarsantri masih belum sesuai dengan rencana tata ruang wilayah kota Surabaya tentang penggunaan lahan. Untuk peta kesesuaian lahan BTKD terhadap RTRW dapat dilihat pada gambar 6 . 


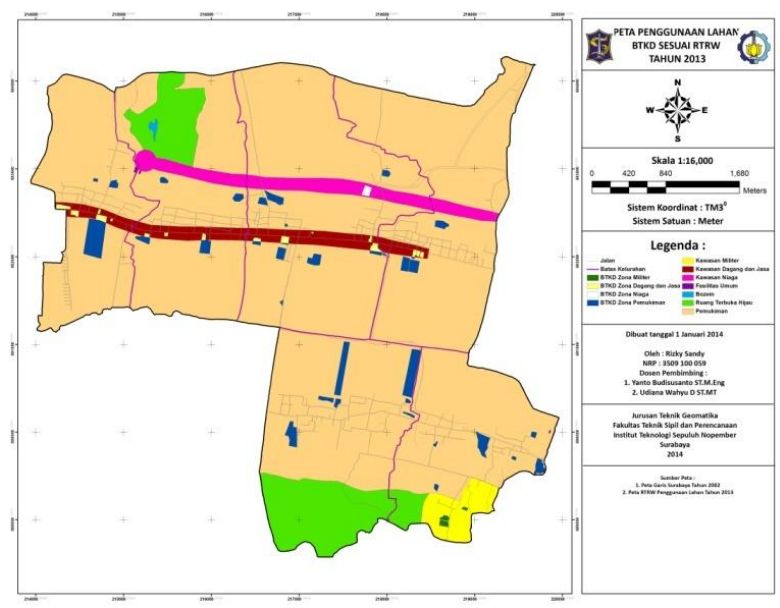

Gambar 6. Peta Sebaran Bekas Tanah Kas Desa Kecamatan Lakarsantri

Hasil evaluasi yang didapat adalah seperti berikut:

1. Kawasan militer termasuk dalam kawasan khusus karena jenis kegiatan yang diwadahi memiliki kondisi dan perlakuan tertentu. Sedangkan ditinjau dari jenis pemanfaatan BTKD yang ada ternyata masih belum memenuhi kebijakan pemanfaatan RTRW yang seharusnya karena pemanfaatannya bukan berupa area khusus melainkan masih berupa makam dan lapangan sepak bola.

2. Sesuai dengan undang-undang RTRW pasal 50 (UU RTRW, 2007), Pada kawasan dagang ada 3 BTKD yang sesuai dengan pemanfaatan RTRW yang seharusnya yakni area pedagang kaki lima dan pasar.

3. Luas kawasan niaga sebesar $611.492 \mathrm{~m}^{2}$ dan hanya ada 1 BTKD yang masuk ke dalam zona kawasan niaga, BTKD tersebut berupa waduk RW I dan RW II terletak di kelurahan lidah kulon dan memiliki luas sebesar $9306 \mathrm{~m}^{2}$. Saat ini BTKD tersebut berfungsi sebagai waduk yang artinya masih belum sesuai dengan penggunaan lahan dari RTRW yang seharusnya berupa kawasan niaga.

4. Sesuai dengan undang-undang RTRW pasal 41 (UU RTRW, 2007) Lokasi pemukiman kembali diarahkan pada kawasan yang memiliki fungsi perumahan dan dapat memanfaatkan lahan milik pemerintah daerah. Pada kawasan ini, pemanfaatan BTKD hampir semuanya sesuai dengan peta RTRW bagian pemukiman seperti kantor kelurahan, Balai RW, sekolahan dan lainnya.

\section{KESIMPULAN DAN SARAN}

Dari penelitian ini dapat diambil beberapa kesimpulan, yaitu :

1. Jumlah bekas tanah kas desa yang tercatat pada tahun 2013 sebanyak 51 buah yang tersebar di 6 kelurahan sedangkan luas total bekas tanah kas desa di kecamatan Lakarsantri pada tahun 2013 adalah sebesar $519.212 \mathrm{~m}^{2}$.

2. Dari hasil analisa dan inventarisasi bekas tanah kas desa didapatkan hasil jenis bangunan 23 bidang dengan luas $219.739 \mathrm{~m}^{2}$ , makam 10 bidang dengan luas $80.305 \mathrm{~m}^{2}$, waduk 9 bidang dengan luas $50.079 \mathrm{~m}^{2}$, sawah 4 bidang dengan luas $129.356 \mathrm{~m}^{2}$, lapangan 3 bidang dengan luas $33.357 \mathrm{~m}^{2}$ dan tegalan 2 bidang $6.446 \mathrm{~m}^{2}$.

3. Evaluasi penggunaan lahan BTKD di kecamatan Lakarsantri untuk saat ini hanya kawasan pemukiman yang sesuai dengan RTRW tahun 2013 dengan rincian luas BTKD untuk kawasan militer sebesar $13.128 \mathrm{~m}^{2}$, kawasan dagang dan jasa sebesar $57.580 \mathrm{~m}^{2}$, kawasan niaga sebesar $9306 \mathrm{~m}^{2}$ dan pemukiman sebesar $439.074 \mathrm{~m}^{2}$.

\section{DAFTAR PUSTAKA}

Undang-Undang Republik Indonesia Nomor 5 . "Tentang perubahan status desa menjadi kelurahan" Jakarta : Presiden RI (1979).

Peraturan Pemerintah Nomor 16 "Tentang Penatagunaan Tanah" Jakarta : Pemerintah (2004).

Undang-Undang Republik Indonesia Pasal 33 . "Pengelolaan Kekayaan Alam" Jakarta : Presiden RI (1945).

Tobing .A, Eksistensi Tanah Bengkok Setelah Berubahnya Pemerintahan Desa menjadi Kelurahan di Kota Salatiga, Tesis Program Pasca Sarjana Magister Kenotariatan Semarang: Universitas Diponegoro (2009).

Undang-Undang Rencana Tata Ruang Wilayah pasal 53 "Tentang kriteria kawasan khusus" Surabaya : Pemerintah (2007).

Undang-Undang Rencana Tata Ruang Wilayah pasal 50 "Tentang kriteria kawasan dagang dan jasa” Surabaya : Pemerintah (2007).

Undang-Undang Rencana Tata Ruang Wilayah pasal 41 "Tentang kriteria pemukiman" Surabaya : Pemerintah (2007). 